\title{
The Development Of Supplementary Books Producing Explanatory Text And Procedure Text With Entrepreneurial Content For Vocational School Student
}

\author{
Yustinah $^{1}$, Fathur Rokhman ${ }^{2}$, Subyantoro $^{3}$, Ida Zulaeha ${ }^{4}$ \\ \{yusti07@gmail.com ${ }^{1}$ \} \\ Universitas Negeri Semarang, Semarang Jawa tengah, Indonesia ${ }^{1,2,3}$
}

\begin{abstract}
The purpose of this study is (1) to analyze the need for supplementary books to produce procedural texts and explanatory texts with entrepreneurial content for vocational school students; (2) to analyze the characteristics of supplementary books producing procedural texts and explanatory texts containing with entrepreneurial content for vocational school students; (3) to compile a supplementary book profile producing procedural text and explanatory text with entrepreneurial content for vocational students, and (4) to test the effectiveness of the supplementary books producing procedural texts and explanatory texts with entrepreneurial content for vocational school students. This research uses the Research and Development (R \& D) approach and method which is carried out in three stages. The results of this study are in the form of Supplementary Books Producing Procedure Texts and Explanatory Texts with Entrepreneurial for Vocational School Students. This developed product can be used as a means of introducing work procedures, supplementary knowledge and skills regarding social phenomena as well as a companion book in learning Indonesian Language on Vocational School regarding Materials of Text Procedures and Explanatory Texts.
\end{abstract}

Keywords: supplementary book, procedure text, explanatory text, entrepreneurial content, entrepreneurship

\section{Introduction}

The main purpose of learning Indonesian Language is to provide the students with an ability to communicate effectively and efficiently in accordance to the applicable ethics, both orally and written (Atmazaki: 2013). This is closely related to the opinion of Mahsun (2014: 39) which states that there are two important components that must be learned in learning language; the meaning and the form. Therefore, the language becomes a means of formation of the ability to think in a systematic, controlled, empirical, and critical way.

Since the function of language is important, efforts are needed to meet the literacy needs. Literacy needs of vocational school students - with 121 specializations - are closely related to the literacy process that is met through productive, adaptive, and normative subjects. This can be observed in the following figure 1 . 


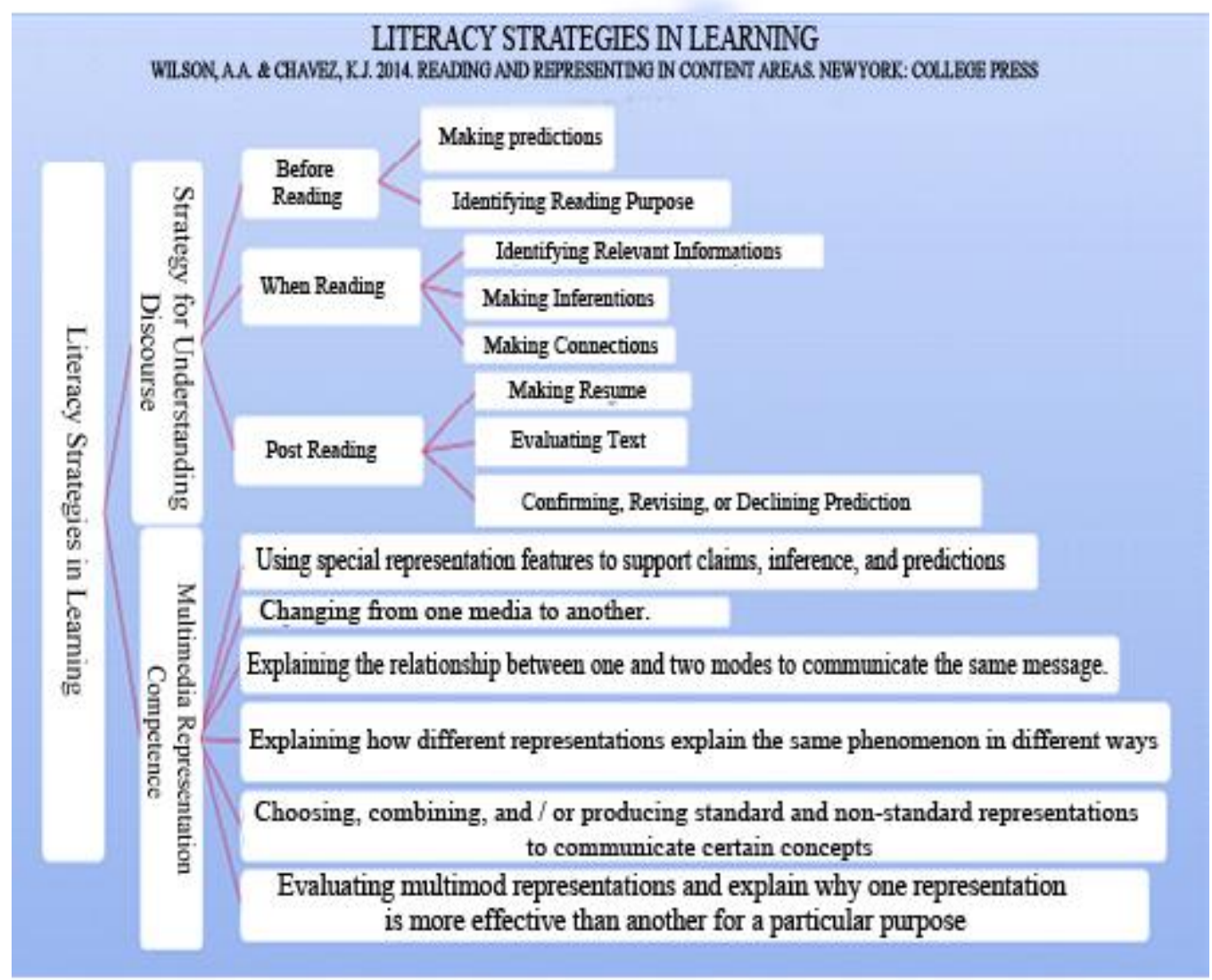

Figure 1. The Framework of Learning Literacy (Source: Ministry of Education and Culture, 2016)

In materializing an effective and efficient Indonesian learning, textbooks have important roles which must be considered. Textbooks by Book Center (2006:1) is a book which is used by learners at certain levels as a medium of learning (instructional), related to the particular field of study which is the standardized and used to support the learning program.

As a support for learning programs in vocational schools, procedure of work and explanation of phenomena are the two important things that must be learned. Work procedures and explanations of phenomena are required for vocational school students to prepare them entering the world of career. Work procedures are studied in the procedural text and an explanation of the phenomena studied in the explanatory text. To meet the needs in learning, a supplementary book need to be made in order to produce entrepreneurial procedure texts and explanatory texts as a companion book.

Regarding the procedure text and explanatory text, several studies have been carried out as below. Researches which are related to the development of supplementary textbooks on entrepreneurial procedures for vocational students that have been carried out include Subyantoro (2012); Riyanto (2013); Sorraya (2014), Purwitasari (2014); Amin (2015); Nurwanti (2015); Wijayanti et al (2015); Komang et al (2015); Setiawan and Rochmiyati 
(2015), Winarsih (2015); Kurniawan and Subyantoro (2016); Sari and Sigalingging (2016); Afandi (2017); Ariati (2016), Al'aliyah (2017); Alam (2017); and Kusumawati (2017).

The studies relating to the development of explanatory text supplementary textbooks containing entrepreneurial for second year vocational schools students which have been carried out include Knapp and Watkins (2005); Riyanto (2013); Vina et al (2013); Kustina and Karlina (2014) Azriani (2014); Asdar (2014); Pradana (2014); Widyaningsih (2014); Melati et al (2014); Astuti (2015); Jayanti (2015); Neina (2015); Purnomo (2015); Primary (2015); Wijayanti (2015); Wulandari et al (2015); Damayanti (2016); Handoko (2016); Mawar (2016); Mikail (2016); Afandi (2017); Azura (2017); Tamba and Lubis (2017); Wassalwa (2017); Yuniawan (2017); and Andriyani (2018).

Based on the research that has been developed previously, the researchers have determined the rationale that underlies this research, namely (1) after the observation it turns out that there is still a need to develop a supplementary book which covers both procedure and explanatory text; (2) both the procedure text materials and explanatory text materials are the new subjects in the 2013 curriculum; (3) the results of the research which are compiled in the form of a companion supplementary book for the existing textbooks is urgently needed; and (4) the supplementary books producing procedural texts and explanatory texts provide additional insight to students in learning the structure, content, and language rules of procedural texts and explanatory texts.

\section{Method}

\subsection{Data Sources}

The data sources which are used in this study are teachers and vocational school students. The data source of supplementary book requirement analysis is obtained from five districts involving five different schools. The selection of these schools is based on the characteristics of schools that excel and distinguished in five different districts / regions. The five schools are the Muhammadiyah Kudus Vocational School, Cluwak Pati 1 State Vocational School, Demak State Vocational School, Semarang 1 State Vocational School, and Ampelgading Pemalang 1 State Vocational School. Data sources are obtained from 10 teachers with 100 students.

The source of supplementary book profile data is based on data from the needs analysis of enrichment books producing procedural texts and explanatory texts with entrepreneurial content for SMK students. The data sources are teachers and experts who also taking role as the validators.

\subsection{Instruments}

The instruments used in this study were questionnaires which are then distributed to the respondents (teachers and students). In the initial stages of the questionnaire, a need analysis of the supplementary book producing the procedural text and the explanatory text with entrepreneurial content for vocational students filled in by the teacher and students from the chosen school. The grid of needs analysis instruments includes the aspects of supplementary books, procedural text aspects, explanatory text aspects, and entrepreneurial aspects.

The aspects of supplementary books have the dimensions which consist of feasibility of content, feasibility of presentation, language feasibility and readability, and feasibility of graphics. The aspects of Procedural text include the aspects of presentation, composition of 
texts, presentation of examples, illustration of images, and format of presentation of paragraphs. The Explanatory text aspects include aspects of presentation, composition of texts, presentation of examples, illustration of images, and format of presentation of paragraphs. Meanwhile, the Entrepreneurship aspects include the application of values, forms of implementation, value groups, additional information related to values, and the format of presenting entrepreneurial values.

The profile of the enrichment book that will be compiled is based on data analysis from the questionnaire for assessing the needs. The enrichment book that is to be tested for the effectiveness is to be validated by four experts and ten teachers. Validated aspects include the dimensions of graphic feasibility, language feasibility, content feasibility, and presentation feasibility. The validated section includes the beginning of the book, the contents of the book, and the end of the book. The text aspects of the procedure include presentation, composition of the text, presentation of examples, illustration of the image, and format of presentation of paragraphs.

Table 1. The Entrepreneurial Content Aspect

\begin{tabular}{|c|c|c|c|c|}
\hline No & Dimension & Aspect & Sub aspect & Total \\
\hline & $\begin{array}{l}\text { Feasibility } \\
\text { Entrepreneurship } \\
\text { Values }\end{array}$ & of Values application & $\begin{array}{l}\text { Implementation } \\
\text { values }\end{array}$ & 1 \\
\hline & & Implementation forms & $\begin{array}{l}\text { Values } \\
\text { implementation } \\
\text { forms }\end{array}$ & 1 \\
\hline & & Groups values & $\begin{array}{l}\text { Presentation } \\
\text { entrepreneurial } \\
\text { values }\end{array}$ & 1 \\
\hline & & $\begin{array}{l}\text { Additional information } \\
\text { about values }\end{array}$ & $\begin{array}{l}\text { Additional } \\
\text { presentation values }\end{array}$ & 1 \\
\hline & & $\begin{array}{l}\text { Format presentation } \\
\text { paragraph }\end{array}$ & $\begin{array}{l}\text { Additional } \\
\text { material } \\
\text { presentation }\end{array}$ & 1 \\
\hline
\end{tabular}

After compiling, the validated supplementary books are later tested at research schools in limited-scale trials, and large-scale trials. The large-scale trials are also carried out with extensive instrument fulfillment in eleven schools that had been prepared. The instrument for testing the effectiveness of the procedure text has the following components: general statement, steps /stages, closure, and presentation model. Meanwhile, the test for the effectiveness of explanatory texts includes general statements, steps, reaffirmations, and presentation models.

\subsection{The Procedure of Research}

Primarily, this research includes three stages, namely the preliminary studies, the development of supplementary books and validation tests, and the assessment of effectiveness in phases/stages. In the preliminary study, the analysis of the needs of the supplementary book as a whole is carried out. After the data regarding the need for supplementary books has been completely obtained, the drafting and development of books are then carried on. 
In the development of supplementary books (supplementary book profiles) the book is carefully compiled according to the requirements analysis obtained from questionnaires involving five different schools by combining the needs analysis of supplementary books according to teachers and students. If different trends are found, steps are taken to pick on higher scores on the trends chosen by the respondents.

In the final stage which is the assessment of effectiveness, testing is carried out periodically. The effectiveness assessment begins from the tests which are conducted at the researched school, followed by a limited scale test in eight different schools, and is developed in a widescale test.

The limited-scale and wide-scale testing provide a simulation of the effectiveness of the supplementary books producing procedural texts and explanatory texts with entrepreneurial content for vocational students both on a limited scale and on a broad scale.

\section{Results}

The results of this study show three phases, namely (1) the phase of needs analysis, (2) the development of prototypes and (3) the phase of assessing effectiveness on the main scale, limited scale, and wide scale.

\subsection{The Phase of Needs Analysis on Supplementary Book Development}

The need to develop supplementary books according to the teachers and students perceptions includes the measures of content and presentation, the measures of language and readability, the measures of graphics, the aspects of procedural texts, the explanatory aspects of the text, and the aspects of entrepreneurship.

The results of the survey show the characteristics of the supplementary book as follows. The first part of the book consists of covers showing the composition of items with striking and interesting colors, is displaying the appropriate images and using font size 12 . The title is located accordingly, contents of the preface are arranged accordingly, the instructions are clear, the table of contents and table of list really facilitate readers in navigating through the books, and finally, the interesting illustrations really help in tweaking the description of content.

The contents of the book include the appropriate titles which have an interesting presentation and proper selection of font styles. The attached images are adjusted to the level of students' comprehension; the graphic designs are made according to the characters. The material contents are adapted according to the needs and the level of comprehension, the explanation and comprehensiveness material are very clear and effective, the provided examples, the utilization of images and explanations, along with detailed colors selection are precisely adjusted with the level of students' understanding. The rest of display of material, presentation of images, and body of text are adjusted to the survey results.

The final part of the book including the bibliography, glossary, back cover and the profile of the author also meet the criteria based on the survey results in table 2 
Table 2. meet the criteria based on the survey results.

\begin{tabular}{|c|c|c|}
\hline $\begin{array}{l}\text { Book } \\
\text { Section }\end{array}$ & Item & Description \\
\hline The & 1 & Color composition on cover conform to students that bright and striking \\
\hline \multirow[t]{9}{*}{ beginning } & 2 & $\begin{array}{l}\text { Display the image on the cover according to the students, namely the book cover } \\
\text { image adjusted to the text }\end{array}$ \\
\hline & 3 & The font size for writing titles according to students is Times New Roman 12 \\
\hline & 4 & $\begin{array}{l}\text { The location of the title on the cover according to the students rules of writing the } \\
\text { title. }\end{array}$ \\
\hline & 5 & $\begin{array}{l}\text { The preface content on the beginning of the book according to the students, which } \\
\text { contains the initial words that deliver (giving an overview of the book to be presented) }\end{array}$ \\
\hline & 6 & $\begin{array}{l}\text { Instructions to use the book make it easier for students to use books so that they are } \\
\text { absolutely present }\end{array}$ \\
\hline & 7 & $\begin{array}{l}\text { The table of contents in the book makes it easier for students to find information in the } \\
\text { book }\end{array}$ \\
\hline & 8 & $\begin{array}{l}\text { List of tables, list of images, list of attachments in the book makes it easier for } \\
\text { students to find tables, images, and attachments in the book }\end{array}$ \\
\hline & 9 & $\begin{array}{l}\text { The illustration of the beginning of the chapter on the enrichment book fits the theme } \\
\text { of the book }\end{array}$ \\
\hline & 10 & $\begin{array}{l}\text { Structuring the page number in an interesting enrichment book for students is placed in } \\
\text { the lower right in a variety of ways }\end{array}$ \\
\hline \multirow{16}{*}{$\begin{array}{l}\text { Book } \\
\text { Contents } \\
\text { Section }\end{array}$} & 11 & $\begin{array}{l}\text { The title of the enrichment book is adapted to the material namely Producing the texts } \\
\text { based on the content for the students }\end{array}$ \\
\hline & 12 & $\begin{array}{l}\text { Description of presentation of enrichment books that attract students' interest, } \\
\text { introduction, material, and examples }\end{array}$ \\
\hline & 13 & $\begin{array}{l}\text { Fonts Selection suit the needs of students by using Times New Roman } 12 \text { with a B5 } \\
\text { paper size }\end{array}$ \\
\hline & 14 & $\begin{array}{l}\text { Images presented in enrichment books that are in accordance with the level of students } \\
\text { understanding contain inspirational images that motivate the students }\end{array}$ \\
\hline & 15 & $\begin{array}{l}\text { Design and color in the books are in accordance with the character of students, namely } \\
\text { attractive color books, pictorial, vary }\end{array}$ \\
\hline & 16 & $\begin{array}{l}\text { The material is presented in accordance with the needs and level of development of } \\
\text { students which includes the text type, text understanding, language structure \& rules }\end{array}$ \\
\hline & 17 & $\begin{array}{l}\text { Explanation of the book material that attracts attention and interest of students is } \\
\text { presented in detail, including the structure and rules of the texts }\end{array}$ \\
\hline & 18 & $\begin{array}{l}\text { The completeness of the material / contents in the book according to the needs of } \\
\text { students is presented from easy material to difficult material }\end{array}$ \\
\hline & 19 & $\begin{array}{l}\text { The material in the enrichment book adds insight to students' knowledge by the } \\
\text { number of pages } 100-160\end{array}$ \\
\hline & 20 & $\begin{array}{l}\text { Explanation of material for enrichment books easily understood by students is } \\
\text { presented according to the structure and rules of the procedure text and explanatory } \\
\text { text }\end{array}$ \\
\hline & 21 & $\begin{array}{l}\text { Examples of entrepreneurial content on the text and books according to the students } \\
\text { needs are presented in the form of text accompanied by photographic images }\end{array}$ \\
\hline & 22 & $\begin{array}{l}\text { The selection of examples in enrichment books is in accordance with the conditions of } \\
\text { students using formal variety by paying attention to the rules of the texts }\end{array}$ \\
\hline & 23 & $\begin{array}{l}\text { Display of illustrated images on enrichment books according to the needs of students, } \\
\text { namely images adapted to the contents of the text associated with entrepreneurial } \\
\text { value }\end{array}$ \\
\hline & 24 & $\begin{array}{l}\text { The use of language presented in the communicative and effective enrichment book } \\
\text { using good and correct Indonesian }\end{array}$ \\
\hline & 25 & $\begin{array}{l}\text { The presentation of additional information regarding knowledge about } \\
\text { entrepreneurship in enrichment books can add insight to students associated with } \\
\text { practice material in Vocational Schools }\end{array}$ \\
\hline & 26 & $\begin{array}{l}\text { Writing analysis at the end of each sample text can make it easier for students to } \\
\text { understand the example of the text presented in the book with an in-depth column that } \\
\text { contains material and analysis. }\end{array}$ \\
\hline
\end{tabular}




\begin{tabular}{|c|c|c|}
\hline \multicolumn{3}{|c|}{27} \\
\hline & & $\begin{array}{l}\text { The presentation of images in each sample of the texts that inspires entrepreneurial } \\
\text { values can add to students' insight, namely the illustration of the picture according to the } \\
\text { contents of the procedure text and explanatory text }\end{array}$ \\
\hline & 28 & $\begin{array}{l}\text { Implementation of entrepreneurial values in the form of groups of values that are implicit } \\
\text { in the text can broaden students' understanding and skills improvement towards the } \\
\text { contents of the texts }\end{array}$ \\
\hline & 29 & $\begin{array}{l}\text { The implementation of entrepreneurial values in the form of groups of values ( } 8 \\
\text { awareness) contained in the texts can broaden the improvement of students' } \\
\text { understanding and skills towards the use of language in the text at the end of each } \\
\text { chapter. }\end{array}$ \\
\hline \multirow{5}{*}{$\begin{array}{l}\text { final } \\
\text { Book } \\
\text { Section }\end{array}$} & 30 & $\begin{array}{l}\text { Presentation of the texts containing entrepreneurial values implicitly and explicitly in the } \\
\text { form of the texts in their entirety and analysis can expand students' understanding and } \\
\text { skills improvement on how to produce text presented in the form of Chapter I, Chapter II, } \\
\text { Chapter II, Chapter IV, Chapter V, and so on }\end{array}$ \\
\hline & 31 & Writing bibliography in enrichment books according to writing rules \\
\hline & 32 & $\begin{array}{l}\text { Writing a glossary in an enrichment book can make it easier for students to understand } \\
\text { difficult terms in a book }\end{array}$ \\
\hline & 33 & $\begin{array}{l}\text { The back cover of the enrichment book is in accordance with the contents of the book as } \\
\text { a whole }\end{array}$ \\
\hline & 34 & Writing the author's profile in the enrichment book fits and meets the criteria \\
\hline
\end{tabular}

\subsection{The Phase of Effectiveness Test}

Phase of Prototype Development. At this stage, the data results of needs analysis for the supplementary book are used to compile the Supplementary Books Producing Text Procedures and Explanatory Texts with Entrepreneurship Contents for Vocational School Students. Starting from the cover, the contents of the book up to the closing, and conclusions and suggestions are all adjusted based on the results of the existing answered-questionnaire. The selection of cover, the development of writing and rules contained within, is congruent with the provisions that have been summarized from the analysis results of needs according to both perceptions of students and teachers.

The Development Phase of the Supplementary Books Producing Text Procedures and Explanatory Texts with Entrepreneurship Contents for Vocational School Students. The development of the supplementary books includes the cover design, the content design, and the book final design which is compatible with the data of needs analysis, the prototype assessment, and the effectiveness testing. From the data above, it is stated that the Supplementary Books Producing Text Procedures and Explanatory Texts with Entrepreneurship Contents for Vocational School Students is declared effective with an average number of $83.5 \%$.

\section{Discussion}

The procedure text and explanatory text are new material for the 2013 curriculum both in the 2016 edition, and in the 2017 edition. These materials need to be developed according to the requirement and needs. The needs for vocational school students in order to produce procedural texts and explanatory texts are urgent because the content, text structure, and linguistic theorem are important to study regarding the usefulness of the text. Therefore, the development of the Supplementary Books Producing Text Procedures and Explanatory Texts with Entrepreneurship Contents for Vocational School Students is an educational demand that cannot be postponed. 
4.1 The Prototype of the Supplementary Books Producing Text Procedures and Explanatory Texts with Entrepreneurship Contents for Vocational School Students

The development of the Supplementary Books Producing Text Procedures and Explanatory Texts with Entrepreneurship Contents for Vocational School Students is carried out in order to support the teaching and learning process in vocational schools which ultimately leads to the increase of knowledge of producing procedure texts and explanatory texts. In addition, the development of this supplementary book is also sought so that there is an expansion in the skills to make procedure texts and explanatory texts with entrepreneurial content for vocational school students

\subsection{The Effectiveness of the Supplementary Books Producing Text Procedures and Explanatory Texts with Entrepreneurship Contents for Vocational School Students}

The effectiveness of enrichment books is represented by the assessments - limited scale and wide scale - illustrates that this supplementary book proved effective to be used on the trial in the appointed vocational schools.

Based on the assessment the supplementary book produces procedural texts and explanatory texts have the effectiveness shown by an average number of $83.5 \%$. This number is quite valid in describing the conditions of the results of the trials that have been carried out. The use of the Supplementary Books Producing Text Procedures and Explanatory Texts with Entrepreneurship Contents for Vocational School Students indicates that the book is effective for vocational school students.

\subsection{Discussion of the Supplementary Books Producing Text Procedures and Explanatory Texts with Entrepreneurship Contents for Vocational School Students.}

Based on the results of these studies, the implications include the following. First, the implications of this enrichment book explain the prospect of future enrichment books, including (1) to grow the entrepreneurship spirit of vocational students in all majors, (2) to enrich and enhancing students' skills in mastering work procedures and natural phenomena and phenomena in social development, (3) to provide a companion book that helps students and teachers in learning.

Secondly, the innovation in supplementary books producing procedural texts and entrepreneurial text for vocational students includes (1) procedural text material and explanatory texts in learning are new material for vocational students in the 2017 edition of the 2013 curriculum, (2) to train students to recognize work procedures and natural phenomena and cultural phenomena in detail and intensely, (3) to provide a positive effect on students in recognizing and developing business spirit as exposed and displayed in the intended supplementary book.

Third, the advantages of this supplementary book are based on physical and content aspects. Based on the physical form, the book is printed with a standard paper size (B5). In terms of appearance, this book is interesting because the cover uses bright and striking colors. According to Siburian (2013: 40), Fauzan and Yusuf (2016: 513) that one of the characteristics of a book that has a strong influence on readers is the interesting presentation display of books. In terms of the contents, the book is quite interesting because it meets the needs of students. Vocational students need work procedures, natural phenomena and social phenomena. Work procedures are found in procedure texts, natural phenomena and social phenomena found in explanatory texts. The suitability of the contents of the book with the needs of students as stated by Purnomo 
(2015: 120) that the supplementary books must be tailored to the needs of students which includes the components of content, language and readability, presentation, and graphics.

Fourth, the weaknesses of the enrichment book produce procedural texts and entrepreneurial charged text for vocational students, namely (1) due to there are 121 specializations in the Vocational School, not all specializations are contained and materialized in the presented contents of procedure texts and the explanatory texts, and (2) there are some materials that are still considered difficult for students to comprehend.

Fifth, the feasibility of supplementary books producing procedural texts and entrepreneurial expansion text for vocational students on a limited or broad scale is considered effective to be used for students. This book is feasible in all four dimensions; Feasibility of content, feasibility of presentation and analysis, feasibility of language and readability, and feasibility of graphics. According to Muslich (2010: 291) the book that has those feasibilities is a quality book.

Based on these five aspects, it can be concluded that the Supplementary Book Producing Text Procedures and Explanatory Texts with Entrepreneurship Contents for Vocational School Students is worthy of use by students and teachers in learning. Although this book has several weaknesses, it also has well prospects, novelty and excellence, and has information on various ways of producing procedural texts and explanatory texts. In terms of knowledge, this book helps students to comprehend and sharpen students' skills regarding the procedure text and explanatory text.

\section{Conclusion}

The development of the Supplementary Book Producing Text Procedures and Explanatory Texts with Entrepreneurship Contents for Vocational School Students is a supplementary book that is suitable to use in vocational schools, all majors whether it is engineering, business or management techniques. Because the procedure text which contains the methods and techniques of doing something is very important for vocational students both in order to equip themselves while in vocational school or to prepare themselves later in career. In addition, the explanatory text is also useful for students in the self-development at school and later in their career to provide explanations in relation to the undertaken works.

Procedure texts and explanatory texts play an important role in a text-based learning. For vocational school students, having entrepreneurship content is a kind of support in preparing the workforce in the future. Therefore, the supplementary book producing procedure texts and explanatory texts for vocational students is urgently needed. 


\section{References}

[1] Afandi, M. I. dan Zulaeha, I. 2017. "Keefektifan Buku Pengayaan Menulis Teks Hasil Observasi Bermuatan Multikultural Berbasis Proyek Baca Tulis untuk Peserta Didik SMP”. Jurnal Pendidikan Bahasa dan Sastra Indonesia. Kebumen. Politeknik Dharma Patria. 6(2).

[2] Atmazaki. 2009. Mengungkap Masa Depan: Inovasi Pembelajaran Bahasa Indonesia dalam Konteks Pengembangan Karakter Cerdas. Makalah. Padang: UNP. 8(2).

[3] Asdar. 2014. "Perangkat Pembelajaran Menulis Teks Eksplanasi Berbasis Model Problem Based Learning Studi Pengembangan pada Siswa Kelas VII SMP N 8 Makasar”. Jurnal Retorika. 9(2): 90-163.

[4] Azura. Arif, S. 2017. "Kemampuan Menulis Teks Prosedur Siswa Kelas VII SMP Negeri 2 Percut Sei Tuan Tahun Pembelajaran 2017/2018". Medan: Jurnal Sastra Unimed. 6(1).

[5] Kemdikbud.2013. Permendikbud no 54 tentang Standar Kompetensi Pendidikan Dasar dan Menengah. Jakarta: Kementrian Pendidikan dan Kebudayaan.

[6] Kemdikbud.2013. Permendikbud no 64 tentang Standar Isi Pendidikan Dasar dan Menengah. Jakarta: Kementrian Pendidikan dan Kebudayaan.

[7] Knapp, P. \& Watkins, M. 2005. Genre, Text, Grammar: Technology for Teaching and Assessing Writing. Australia: University of New South Wales Press

[8] Kustina, R. \& Karlina, H. 2014. "Efektivitas Pembelajaran Kooperatif Tipe Team Assisted Individualization (TAI) dalam Materi Pengenalan Struktur Eksplanasi pada Siswa Kelas VIII SMP N3 Banda Aceh", Visipena.5(2). Banda Aceh: STIKIP Bina Bangsa Getsempena.

[9] Muslich, Mansur. 2010. Text Book Writing. Jakarta: Ar-Ruzz Media

[10] Purnomo, P., Zulaeha, I., Subyantoro. 2015. "Pengembangan Buku Pengayaan Menulis Teks Eksposisi Bermuatan Nilainilai Sosial untuk Siswa SMP”. Seloka: Jurnal Pendidikan Bahasa dan Sastra Indonesia, 4 (2). Semarang: Universitas Negeri Semarang.

[11] Riyanto, A. 2013. "Pengembangan Buku Pengayaan Keterampilan Membaca Bahasa Indonesia yang Bermuatan Nilai Kewirausahaan”. Seloka: Jurnal Pendidikan Bahasa dan Sastra Indonesia, 2 (1). Semarang: Universitas Negeri Semarang

[12] Siburian, T, A., Malan L. 2018. "The Development Of Teaching Material Of Writing Complex Procedure Text Based Thinking Map On X Grade Students Of State Vocational School 7 Medan Nopia Epalen” International Journal of Education, Learning and Development. 6(1): 56-70. Medan.

[13] Tamba, A. M. \& Lubis. F. 2017. Kemampuan Memproduksi Teks Eksplanasi Berdasarkan Isi, Struktur, dan Ciri Kebahasaan oleh Siswa Kelas XI SMK Multi Karya Tahun Pembelajaran 2016/2017. Kode: Jurnal Bahasa Unimed. 5(3).

[14] Wulandari, M. Y., Sulissusiawan, A., \& Syambasril. 2015. Pembelajaran Menulis Teks Eksplanasi Kurikulum 2013 pada Siswa SMA Kemala Bhayangkari Kabupaten Kubu Raya. JIPP: Jurnal Pendidikan dan Pembelajaran Untan. 5(1). Pontianak: Pendidikan Bahasa Indonesia FKIP UNTAN.

[15] Yuniawan, D., Mardikantoro, H. B. 2017. "Peningkatan Keterampilan Merevisi Teks Eksplanasi Menggunakan Metode Team Accelerated Instruction (TAI) pada Siswa Kelas Vii SMP Negeri 12 Magelang Tahun Pelajaran 2015/2016”. Jurnal Pendidikan Bahasa dan Sastra Indonesia, 6 (2). Semarang: Universitas Negeri Semarang. 